\title{
ПЕДАГОГІЧНІ ІННОВАЦІЇ У ПРАКТИЦІ ДІЯЛЬНОСТІ ЗАКЛАДІВ ЗАГАЛЬНОЇ СЕРЕДНЬОЇ ОСВІТИ
}

\author{
Швидун В. М. \\ кандидат педагогічних наук, дочент, \\ директор \\ Навчально-науковий інститут педагогіки \\ КЗВО «Дніпровська академія неперервної освіти» Дніпропетровської обласної ради \\ вул. Володимира Антоновича, 70, Дніпро, Україна \\ orcid.org/0000-0002-5450-9043 \\ Shvidun2006@ukr.net
}

\begin{abstract}
Ключові слова: якість освіти, традиційна система освіти, освітня парадигма, освітнє середовище, педагогічні технологї.
\end{abstract}

У статті здійснено аналіз сучасного стану якості шкільної освіти України на основі участі українських школярів у міжнародних дослідженнях якості освіти та опитувань батьків, учнів, роботодавців. Констатується факт про невідповідність очікувань суспільства стосовно підготовки учнів у закладах загальної середньої освіти та реального стану речей через неготовність випускників до виконання завдань, що передбачають інтеграцію теоретичних та практичних знань, застосування їх для з'ясування суті явищ, що відбуваються у навколишньому світі, перенесення знань у нові умови та застосування на практиці, генерування власних способів реалізації знань на підставі аналізу наявних фактів.

Обгрунтовується теза про те, що для вирішення наявних суперечностей між теорією й практикою освітньої діяльності та вимогами суспільства до системи освіти доцільно запроваджувати освітні та педагогічні інновації. Визначено позитивні та негативні аспекти традиційної системи освіти, проаналізовано термін «інновація», звернено увагу на необхідність дотримання системи під час організації та управління інноваційною діяльністю в закладі освіти.

Акцентується увага на необхідності враховувати наявність певних суперечностей, з якими стикаються педагоги у своїй практичній діяльності: невідповідністю традиційних методів навчання та виховання учнів сучасним вимогам до освіти; обмеженістю термінів навчання та швидкістю оновлення інформації; непідготовленістю конкретного педагога до впровадження інновацій на належному рівні; прагненням новаторів оновлювати навчально-виховний процес та протидією з боку консервативно налаштованих колег тощо.

Із метою вирішення означених проблем пропонується під час навчання здобувачів вищої освіти - майбутніх педагогів та під час підвищення кваліфікації педагогічних працівників здійснювати низку заходів: включати у зміст навчальних планів та програм дисципліни, що містять інформацію про педагогічну інноватику; ознайомлювати з інноваційним методами та формами навчання: діалоговими, діагностичними, активними, інтерактивними, дистанційними, комп'ютерними, тренінговими, проєктними тощо; рекомендувати органічно поєднувати інноваційні методики 3 класичними, традиційними, продумано й гармонічно підбирати різні методи щодо кожної дисципліни та кожного заняття залежно від їх мети та специфіки; розвивати особистісні установки педагогів; орієнтувати на необхідність спільного проєктування навчального процесу; пропагувати потребу зміни функцій міжособистісного спілкування між учителем та учнями. 


\title{
PEDAGOGICAL INNOVATIONS IN THE PRACTICAL ACTIVITY OF GENERAL SECONDARY EDUCATION INSTITUTIONS
}

\author{
Shvydun V. M. \\ Candidate of Pedagogical Sciences, Associate Professor, \\ Director \\ Educational and Scientific Institute of Pedagogy \\ of the Communal Institution of Higher Education «Dnipro Academy of Continuing Education» \\ of Dnipropetrovsk Regional Council \\ Volodymyr Antonovych str., 70, Dnipro, Ukraine \\ orcid.org/0000-0002-5450-9043 \\ Shvidun2006@ukr.net
}

\begin{abstract}
Key words: quality of education, traditional system of education, educational paradigm, educational environment, pedagogical technologies.
\end{abstract}

The article reveals the analysis of the current state of quality of school education in Ukraine based on the participation of Ukrainian students in international studies of the quality of education and the surveys among parents, students, and employers. We observe certain contradictions between the expectations of the society regarding students' training in general secondary education institutions and the reality due to graduates' unpreparedness to perform tasks involving the integration of theoretical and practical knowledge, its use to clarify the phenomena occurring in the world, knowledge transfer in new conditions and its practical application generating own ways of knowledge realization based on the analysis of the available facts.

The thesis is substantiated that it is reasonable to introduce educational and pedagogical innovations in order to resolve the existing contradictions between the theory and practice of educational activities and the requirements of the society to the education system.

The positive and negative aspects of the traditional education system are identified; the term "innovation" is analyzed. We also focus on the importance to comply with the system while organizing and managing innovation activities in the educational institution.

We emphasize on the necessity to take into account certain contradictions that teachers face in their practice: the inconsistency between traditional methods of teaching and educating students and modern requirements for education; limited training time and speed of updating information; a particular teacher's unpreparedness to implement innovations at the appropriate level; innovators' desire to update the educational process and conservative colleagues' opponency, etc.

In order to solve these issues, it is proposed to carry out a number of measures during the training of applicants for higher education, who are future teachers, and during teachers' advanced training courses: to include the disciplines that contain information about pedagogical innovation in the content of curricula and programs; to introduce innovative methods and forms of training such as dialogic, diagnostic, active, interactive, distance, computer, training, project, etc; to recommend combining seamlessly innovative methods and classical, traditional ones, as well as selecting thoughtfully and harmoniously different methods for each discipline and each lesson depending on their purpose and specificity; to develop teachers' personal attitudes; to focus on the need for joint design of the educational process; to promote changing the functions of interpersonal communication between a teacher and students. 
Постановка проблеми. Участь українських школярів у міжнародних дослідженнях якості освіти TIMSS та PISA дає змогу зробити висновок про незадовільний рівень підготовки учнів. Нетрадиційна постановка теоретичних питань, необхідність інтеграції теоретичних та практичних знань, застосування їх для з'ясування суті явищ, що відбуваються у навколишньому світі, перенесення знань у нові умови та застосування на практиці, потреба в генеруванні власних способів реалізації знань на підставі аналізу наявних фактів значно знизили результативність відповідей.

Опитування стосовно якості шкільної освіти, що проводяться різними організаціями, зокрема й Українським інститутом майбутнього, серед батьків, учнів, роботодавців, свідчать, що традиційне провідне завдання будь-якої ланки освіти - формування глибоких, енциклопедичних знань утратило свою актуальність і знаходиться не на перших місцях серед вимог до випускників закладів освіти [8].

Пріоритетними є: уміння самостійно вчитися; здатність до творчого вирішення практичних завдань; уміння гнучко адаптуватися до мінливих життєвих ситуацій; самостійне та критичне мислення; усвідомлення, де і в який спосіб отримані теоретичні знання можуть бути реалізовані; навички роботи з інформацією (збирати необхідні факти, аналізувати їх, висувати гіпотези, робити узагальнення, аргументовані висновки) тощо.

Усе це $\epsilon$ підставою для кардинальних змін в організації навчального процесу, орієнтації системи освіти на комплексну підготовку учнів до життя на відміну від традиційного формування знань, умінь, навичок через упровадження у практику діяльності закладів загальної середньої освіти педагогічних інновацій.

Дослідження у даному напрямі представлені значною кількістю робіт як українських, так і зарубіжних учених, зокрема: Л. Вагіної, Ф. Ващука, О. Дубасенюк, Г. Єльникової, Ю. Конаржевського, Ю. Бугана, О. Боднар, О. Попової, С. Дея, М. Ерота, М. Хабермана, Г. Бредлі та ін. Відзначаючи значний доробок науковців щодо дослідження поняття «інновація» та впровадження їх у систему освіти, уважаємо доцільним запропонувати авторське бачення даного поняття та окреслити конкретні заходи, що сприятимуть більш активному використанню педагогічних інновацій у практиці діяльності закладів загальної середньої освіти.

Мета статті. Головною метою роботи $\epsilon$ доведення тези про необхідність дослідження й оперативного вирішення суперечностей, які виникають між теорією й практикою освітньої діяльності та вимогами суспільства до системи освіти, доцільність запровадження освітніх та педагогічних інновацій.
Виклад основного матеріалу дослідження. Традиційна система освіти, започаткована ще Я.А. Коменським, дотепер $є$ основною у навчальних закладах світу. Уважаємо доцільним зазначити, що вона має як позитивні, так і негативні аспекти. Позитивні:

- можливість за обмежений час передати великі обсяги теоретичної інформації та надати зразки їх застосування в аналогічних ситуаціях;

- забезпечення глибини та міцності отриманих знань, швидке формування вмінь і навичок;

- колективний характер засвоєння інформації, що дає змогу виявляти типові помилки та усувати їх;

- учень працює у тісному контакті з учителем, його відповіді являють собою розгорнутий усний звіт, що позитивно впливає на розвиток культури мовлення;

- учитель, використовуючи додаткові джерела, може сформувати в учнів пізнавальну мотивацію.

Негативні:

- учні отримують знання у готовому вигляді як аксіому, що не потребує доведення;

- формуються навички використання інформації за зразком в аналогічних ситуаціях;

- орієнтація переважно на запам'ятовування, репродуктивне відтворення, а не на мислення;

- мало сприяє розвитку творчості, активності, самостійності;

- недостатньо враховуються індивідуальні особливості учнів;

- превалює суб'єкт-об'єктний варіант відносин учителя та учнів.

Інтеграція української системи освіти до європейського та світового освітнього простору зумовлює необхідність трансформації освітньої парадигми 3 функціональної підготовки до компетентнісного розвитку особистості. У цьому контексті доцільно говорити про необхідність упровадження в практику роботи закладів загальної середньої освіти педагогічних та освітніх інновацій.

Термін «інновація» не новий, але не має однозначного трактування. Зокрема, А. Никифоров визначає інновацію як «...загальносоціологічну категорію, результат і спонукальний мотив прогресу суспільства в усій його багатовимірності» [3, с. 224].

О. Попова визначає інновацію як «...цілеспрямований і керований процес внесення змін в освітню практику шляхом створення, розповсюдження та освоєння новацій» [6, с. 14].

С. Крисюк уважає, що в основі інновацій в освіті мають бути кілька важливих проблем:

«1) створення на рівні держави і суспільства умов, які сприяють активізації діяльності освітніх організацій в інноваційній сфері управління;

2) вивчення, узагальнення і поширення передового педагогічного досвіду; 
3) запровадження досягнень психолого-педагогічної науки в практику» $[4$, с. 64$]$.

О. Дубасенюк указує на те, що «...сутнісною ознакою інновації є іiї здатність впливати на загальний рівень професійної діяльності педагога, розширювати інноваційне поле освітнього середовища у навчальному закладі, регіоні» [2]. Розвиваючи думку, дослідник відзначає, що «...як системне утворення інновація характеризується інтегральними якостями: інноваційний процес, інноваційна діяльність, інноваційний потенціал, інноваційне середовище. Джерелом інновації $€$ цілеспрямований пошук ідеї з метою розв'язання суперечностей, iї освоєння відбувається шляхом апробації у формі педагогічного експерименту або пілотного впровадження» [2].

Глосарій Європейського фонду освіти пояснює, що «...інновації - це вперше впроваджена новизна, однак більшість інновацій пов'язана 3 перенесенням існуючих підходів у нові умови шляхом їх адаптації або із внесенням поступових змін до існуючих систем» [1, с. 295].

Т. Туркот відзначає, що «інновація освіти цілеспрямований процес змін, що ведуть до модифікації мети, змісту, методів, форм навчання й виховання, адаптації процесу навчання до нових вимог» [7, с. 183].

У своєму дослідженні ми поділяємо визначення інновації, наведене О. Дубасенюком: «...інновації в освіті - це процес творення, запровадження та поширення в освітній практиці нових ідей, засобів, педагогічних та управлінських технологій, у результаті яких підвищуються показники (рівні) досягнень структурних компонентів освіти, відбувається перехід системи до якісно іншого стану» [2].

На підставі проведеного аналізу констатуємо, що інновація - це нововведення, яке передбачає виникнення інноваційної ідеї, створення на основі ідеї модернізованої або зовсім нової розробки та іiї впровадження у практику.

О. Мариновська відзначає, що під час організації та управління інноваційною діяльністю у закладі освіти необхідно дотримуватися певної системи, тобто розробити та реалізувати на: «...стратегічному рівні - систему управління інноваційною діяльністю; тактичному рівні - відповідну програму управління інноваційною діяльністю; операційному рівні - локальні плани роботи відповідно до програми» [5, с. 367].

Додатково зазначимо, що під час реалізації інновацій також необхідно враховувати наявність певних суперечностей, 3 якими стикаються педагоги у своїй практичній діяльності: невідповідністю традиційних методів навчання та виховання учнів новим - особистісно зорієнтованому навчанню, формуванню компетентностей тощо; обмеженістю термінів навчання та швидкістю оновлення інформації, що призводить до проблеми вибору оптимального рівня знань, необхідного сучасній людині; непідготовленістю конкретного педагога до впровадження інновацій на належному рівні; прагненням новаторів оновлювати навчально-виховний процес та протидією 3 боку консервативно налаштованих колег тощо.

На нашу думку, під час організації навчання здобувачів вищої освіти - майбутніх педагогів та під час підвищення кваліфікації педагогічних працівників доцільно:

- включати у зміст навчальних планів та програм дисципліни, що містять інформацію про педагогічну інноватику;

- ознайомлювати 3 інноваційним методами та формами навчання: діалоговими, діагностичними, активними, інтерактивними, дистанційними, комп'ютерними, тренінговими, проєктними тощо;

- рекомендувати органічно поєднувати інноваційні методики з класичними, традиційними, продумано й гармонічно підбирати різні методи щодо кожної дисципліни та кожного заняття залежно від їх мети та специфіки;

- розвивати особистісні установки педагогів, оскільки навчальний процес має бути діалогом особистостей учителя та учнів, що суттєво поліпшує мотивацію до навчання;

- орієнтувати на необхідність спільного проєктування навчального процесу;

- пропагувати потребу зміни функцій міжособистісного спілкування між учителем та учнями (педагог має бути фасилітатором).

Висновки. Таким чином, здійснивши аналіз доцільності використання педагогічних інновацій у практиці діяльності закладів загальної середньої освіти, ми дійшли певних висновків. Традиційна система освіти, превалююча сьогодні в Україні, не повною мірою відповідає запитам учнів, батьків, суспільства на підготовку творчої особистості, здатної використовувати теоретичні знання у практичних, у тому числі й нестандартних, ситуаціях, бути готовою до конкурентоспроможної діяльності. Для оперативної зміни ситуації в системі освіти, розв'язання суперечностей, що виникають між теорією й практикою освітньої діяльності та вимогами суспільства до системи освіти, на нашу думку, доцільно зорієнтувати вчителів на запровадження освітніх та педагогічних інновацій у закладах загальної середньої освіти.

Подальші дослідження у цьому напрямі будуть спрямовані на вивчення досвіду впровадження освітніх інновацій у систему освіти зарубіжних колег та можливості його використання в Україні. 


\section{ЛІТЕРАТУРА}

1. Ващук Ф.Г. Перехід до інноваційних технологій у вищій освіті - вимога часу : монографія. Ужгород : ЗакДУ, 2011. $560 \mathrm{c.}$

2. Дубасенюк О.А. Інновації в сучасній освіті. Інновачії в освіті: інтеграчія науки $i$ практики : збірник науково-методичних праць. Житомир : ЖДУ ім. I. Франка, 2014. C. 12-28. URL: https://core.ac.uk/download/pdf/42971148.pdf (дата звернення: 22.04.2021).

3. Енциклопедія державного управління : у 8 т. / редкол.: Ю.В. Ковбасюк (гол.) та ін. Київ : НАДУ, 2011. T. 4. 324 c.

4. Крисюк С.В. Становлення та розвиток післядипломної освіти педагогічних кадрів України (1917-1941рр.). Київ : УІПКККО, 1995. 174 с.

5. Мариновська О.Я. Педагогічна інноватика. Менеджмент інновачій : навчально-методичний посібник. Івано-Франківськ : Місто НВ, 2019. 504 с.

6. Попова О.В. Становлення і розвиток інноваційних педагогічних ідей в Україні у ХХ столітті : монографія. Харків : ОВС, 2001.255 с.

7. Туркот T.I. Педагогіка вищої школи : навчальний посібник. Київ : Кондор, 2011. 628 с.

8. Якість шкільної освіти у 5-9 кл. Результати опитування батьків. URL: https://nus.org.ua/wp-content/ uploads/2019/03/Analiz-vidpovidey-.pdf (дата звернення: 21.04.2021).

\section{REFERENCES}

1. Vashchuk F.H. (2011) Perekhid do innovatsiinykh tekhnolohii u vyshchii osviti - vymoha chasu [Transition to innovative technologies in higher education - a requirement of the time]. A monograph. Uzhhorod: ZakSU.560 p.

2. Dubaseniuk O.A. (2014) Innovatsii v suchasnii osviti [Innovations in modern education]. Innovations in education: integration of science and practice: a collection of scientific and methodical works. Zhytomyr: ZhSU Publishing House. I. Franko. P. 12-28.URL: https://core.ac.uk/download/pdf/42971148.pdf

3. (2011) Entsyklopediia derzhavnoho upravlinnia [Encyclopedia of public administration: in 8 volumes]. Nat. acad. state management. Vol.4. 324 p.

4. Krysiuk S.V. (1995) Stanovlennia ta rozvytok pisliadyplomnoi osvity pedahohichnykh kadriv Ukrainy (1917-1941 rr.) [Formation and development of postgraduate education of pedagogical staff of Ukraine (1917-1941). Kyiv: UIPKKKO. 174 p.

5. Marynovska O.Ia. (2019) Pedahohichna innovatyka. Menedzhment innovatsii [Pedagogical innovation. Innovation management. Ivano-Frankivsk: City of NV. 504 p.

6. Popova O.V. (2001) Stanovlennia i rozvytok innovatsiinykh pedahohichnykh idei v Ukraini u XX stolitti [Formation and development of innovative pedagogical ideas in Ukraine in the twentieth century]. Kharkiv: OVS. 255 p.

7. Turkot T.I. (2011) Pedahohika vyshchoi shkoly [Pedagogy of High School]. Kyiv: Kondor. 628 p.

8. Iakist shkilnoi osvity u 5-9 kl. Rezultaty opytuvannia batkiv [The quality of school education in grades 5-9. Results of the survey of fathers]. URL: https://nus.org.ua/wp-content/uploads/2019/03/ Analiz-vidpovidey-.pdf. 